
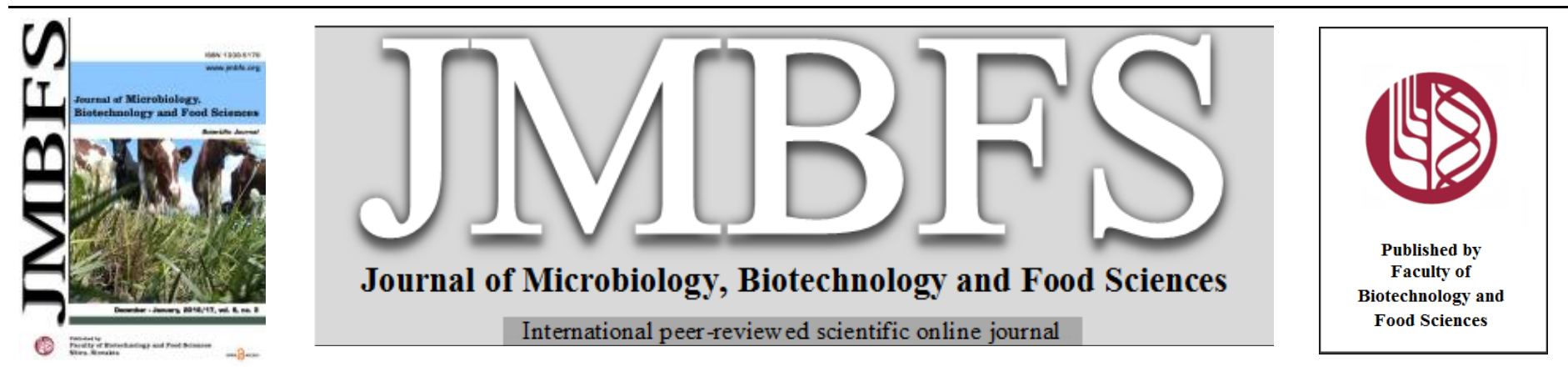

\title{
ANTIBACTERIAL ACTIVITY OF OZONIZED OLIVE (OLEA EUROPAEA L.) AND VENADILLO (SWIETENIA HUMILIS ZUCC.) OILS AGAINST ESCHERICHIA COLI AND STAPHYLOCOCCUS AUREUS
}

\author{
Marcela Soto Beltran ${ }^{1}$, Maribel Jiménez ${ }^{l}$, Bianca A. Amézquita-López ${ }^{l}$, Célida Martínez-Rodriguez $z^{2}$ Cristobal Chaidez ${ }^{2}{ }^{*}$
}

\author{
$\operatorname{Address(es):~}$ \\ ${ }_{1}^{1}$ Universidad Autónoma de Sinaloa, Facultad de Ciencias Químico Biológicas. Universitaria S/N, Ciudad Universitaria, 80040 Culiacán, Sinaloa, México. Tel: +152 \\ 6677137860 . \\ ${ }^{2}$ National Food Safety Laboratory Research. Carretera a Eldorado Km 5.5, Col. Campo El Diez, 80129, Culiacán, Sinaloa, México. Tel/Fax: +52 667 7605536 (37).
}

*Corresponding author: chaqui@ ciad.edu.com

doi: 10.15414/jmbfs.2016/17.6.3.947-949

ARTICLE INFO

Received 2. 12. 2015

Revised 11. 10. 2016

Accepted 20. 10. 2016

Published 1. 12. 2016

Short communication

open $\bigodot_{\text {ACCESS }}$

\begin{abstract}
Ozonized oils are antimicrobial agents obtained from the combination of ozone and unsaturated fatty acids of vegetables oils. The aim of the present study was to evaluate the antimicrobial effectiveness of ozonized olive oil (OOO) and ozonized venadillo oil (OVO) against Escherichia coli and Staphylococcus aureus. The antibacterial activity was conducted by the agar dilution method to determine the minimum inhibitory concentration (MIC) and the bacterial Log10 reduction. The lowest MIC $(4.5 \mathrm{mg} / \mathrm{mL})$ against E. coli was obtained when $\mathrm{OOO}$ and $\mathrm{OVO}$ were ozonized during 12 and 6 hours, with $2.5 \log 10$ of bacterial reduction, respectively; while, the lowest MIC against $S$. aureus $(1.5 \mathrm{mg} / \mathrm{mL})$ was obtained when OVO was ozonized during 6 hours, with $3.4 \log 10$ of bacterial reduction. The $\mathrm{OOO}$ reached peroxide values of 642.53 and $703.7 \mathrm{mmol}-$ equiv/kg after 6 and 12 hours, respectively, while an 892.12 mmol-equiv/kg was obtained after 6 hours for OVO. Data reported here suggest that both ozonized oils are promising effective treatment for bacterial infections.
\end{abstract}

Keywords: Bactericide; Ozonized oils; Venadillo oil; Escherichia coli; Staphylococcus aureus

\section{INTRODUCTION}

In the past fifty years, the proliferation of antimicrobial agents for use in humans and animals has placed an unprecedented pressure on microorganisms. Thus, drug resistant bacteria have led to look for natural antibacterial products such as vegetables oils. Plants and their essential oils are potentially useful sources of antimicrobial compounds, such as phenolic acid, carvacrol, terpenes, terpenoids and geraniol (Alonso-Castro et al., 2011; Association of Analytical Communities, 1969; Bakkali et al., 2008; Bassolé and Juliani, 2012; Burt, 2004). The application of natural oils is wide, ranging from skin to periodontal infections; they had also been proposed for cancer treatment, food preservation, as well as aromatherapy and the fragrances industries (Christaki et al., 2012). Another alternative for the treatment of infectious diseases is the use of ozone. Ozone is a powerful oxidizer, does not contaminate the atmosphere, possess an antimicrobial effect, and has not been reported with bacterial resistance. Ozone has been used against cutaneous infections, otitis, vaginitis, and dentistry interventions (Criegee, 2003; Díaz et al., 2006; do Amarante et al., 2013) Additionally, application of ozone on infections caused by Escherichia coli and Staphylococcus aureus had been reported (Geweely, 2006; Guinesi et al., 2011; Jiménez et al., 1997). The therapeutic antimicrobial properties of ozone are due to the formation of oxidized compounds, such as hydrogen peroxide, hydroperoxides, aldehydes and ozonides which are formed when the polyunsaturated fatty acids presents in vegetable oils make contact with ozone (Kon and Rai, 2012).

Over the last decade, many ozonized oils have been introduced as alternative for bacterial infections. Among those, ozonized sunflower oil (OLEOZON) and pure olive oil have been proven to have a broad antibacterial spectrum that covers Gram negative and Gram positive (Geweely, 2006; Guinesi et al., 2011; Ledea et al., 2010; Lezcano et al., 1998). The reaction between ozone and olive oil occur at the carbon-carbon double bonds present in unsaturated fatty acid producing different toxic products such as oxygenated compounds, hydroperoxides, ozonides, aldehydes, peroxides and polyperoxide which could be responsible for the wide antimicrobial activity of ozonized olive oil (Kon and Rai, 2012). Díaz et al. (2006) and Lezcano et al. (1998) assessed the antimicrobial activity of ozonized olive oil during 5 hours, showing a greater resistance against $E$. coli than $S$. aureus with a minimum inhibitory concentration of $9.5 \mathrm{mg} / \mathrm{mL}$ and $4.5 \mathrm{mg} / \mathrm{mL}$, respectively. Venadillo tree (Swietenia humilis
Zucc.) belongs to the Meliaceae family. It can be found along the Mexican and Central America Pacific coast. The secondary metabolites of venadillo tree mainly limonoids, represents a natural option to endemic microbial infections, which are traditionally used as infusions or ointments (López-Pantoja et al., 2007; Martínez et al., 2006; Millezi et al., 2012). Lopez-Pantoja et al. (2007) and Montevecchi et al. (2013) evaluated the antimicrobial activity of venadillo ethanolic extracts at $50 \%$ concentration, against $E$. coli and S. aureus, reporting the complete inhibition of growth of both microorganisms. The high content of polyunsaturated fatty acids of venadillo tree combines with ozone may potentiate the antimicrobial activity of the oil (Martínez et al., 2006). The objective of the present study was to evaluate the ozonized olive oil (OOO) and ozonized venadillo oil (OVO) against Escherichia coli and Staphylococcus aureus.

\section{MATERIAL AND METHODS}

\section{Strains}

Positive control strains of Escherichia coli ATCC 700609 and Staphylococcus aureus ATCC 29213 were obtained from the State Laboratory of Public Health of Sinaloa and the National Food Safety Laboratory Research, respectively. Both bacterial strains were used for the antimicrobial assays.

\section{Ozone generation}

Ozone was generated using the OzoneLabTM OL80F/DST-2S Desktop Ozone Generator (DST Lab, Canada) by passing Oxygen gas with an electric chamber at a fixed voltage $(120 \mathrm{~V})$ and a constant flow rate of $481 \mathrm{mg} /$ hour.

\section{Olive and venadillo oils preparation}

Olive oil was commercially acquired and venadillo oil was obtained by seeds ethanolic extraction as described by López-Pantoja et al. (2007) and Montevecchi et al. (2013).

Olive and venadillo oils ozonization

Ozonization was carried out during two periods of time, 6 and 12 hours for olive 
oil, and 6 hours for venadillo oil. The venadillo oil was not ozonized during 12 hours because the peroxide value reached during 6 hours of ozonization was higher than those reached by ozonized olive oils. The ozone flow was 62 $\mathrm{mL} / \mathrm{minute}$ with an output stream of $481 \mathrm{mg} /$ hour. Additionally, commercially olive and venadillo oils were ozonized and used as standard for comparison. The resulted ozonized oils were named OOO and OVO for olive and venadillo, respectively.

\section{Peroxide determination}

The peroxide value of each sample was determined using the officia methodology of AOAC 965.33 as followed: $0.5 \mathrm{~g}$ of each oil sample were placed in an Erlenmeyer flask with $30 \mathrm{~mL}$ of chloroform-acetic acid (3:2 v/v) (JT Baker) solution and stirred bar until dissolved. After this, $0.5 \mathrm{~mL}$ of a saturated potassium iodide (KI) solution was added and allowed to stand for 3 minutes Subsequently, $30 \mathrm{~mL}$ of water were added to the flask followed by titration using $0.1 \mathrm{~N}$ sodium thiosulphate, until the color changed from yellow to light yellow. Finally, $0.5 \mathrm{~mL}$ of $1 \%$ starch solution was added and stirred to release the iodine from the chloroform layer (Perez-Rubio et al., 2012).

\section{Inoculum preparation}

Escherichia coli ATCC 700609 and Staphylococcus aureus ATCC 29213 were grown in tripticasein soy broth (TSB) (Bioxon, USA), and incubated for 24 hours at $37^{\circ} \mathrm{C}$, separately. Each organism was purified by centrifugation at $13080 \mathrm{~g}$ for 10 minutes at $4^{\circ} \mathrm{C}$. The suspension was washed twice with $20 \mathrm{~mL}$ of phosphate monobasic buffer $\left(\mathrm{KH}_{2} \mathrm{PO}_{4}\right)$, then adjusted with $5 \mathrm{~mL}$ of $\mathrm{KH}_{2} \mathrm{PO}_{4}$ buffer and refrigerated at $4^{\circ} \mathrm{C}$ (Lopez-Pantoja et al., 2007). Decimal dilutions were prepared to determine the final inoculums concentration of E. coli ( 1 x $10^{4}$ $\mathrm{CFU} / \mathrm{mL})$ and Staphylococcus aureus $\left(1 \times 10^{7} \mathrm{CFU} / \mathrm{mL}\right)$.

\section{Minimum inhibitory concentration (MICs)}

MICs were determined by the agar dilution method according to the Nationa Committee for Clinical Laboratory Standardization (NCCLS) guidelines. Al susceptibility tests were repeated three times. The prepared ozonized oils were previously sterilized for 1 hour using UV light $(360 \mathrm{~nm})$ and added in serial dilutions from $1 \mathrm{mg} / \mathrm{mL}$ to $10 \mathrm{mg} / \mathrm{mL}$, per separate, to Mueller Hinton aga plates, to finally be dried out at room temperature in a laminar flow hood (Envirco, USA). Subsequently, an inoculum of the selected bacteria was widespread at the surface of the agar-ozonized oils mixture and incubated 24 hours at $37^{\circ} \mathrm{C}$. After incubation, the Petri dishes were placed on a dark nonrefracting surface and the MICs were recorded as the lowest concentration of $\mathrm{OOO}$ and OVO inhibiting visible bacterial growth.

\section{Bacterial $\log 10$ reduction}

This procedure was conducted once the MIC's values were determined for each ozonized oil and each concentration as followed: $10 \mathrm{~mL}$ of each prepared TSB ozonized oil mixture was inoculated with $E$. coli at $1 \times 10^{4} \mathrm{CFU} / \mathrm{mL}$ and $S$. aureus at $1 \times 10^{7} \mathrm{CFU} / \mathrm{mL}$ followed by incubations for 24 hours at $37^{\circ} \mathrm{C}$. After the incubation period, decimal dilutions were prepared from each concentration and plated on m-FC agar (m-FC) (DIFCO, USA) and Mannitol Salt Agar (MSA) (DIFCO, USA) for E. coli and S. aureus, and incubated at 45 and $37^{\circ} \mathrm{C}$ for 24 hours, respectively. Finally, the colony forming units (CFU) were quantified in a colony counter (SOL-BAT brand), model Q-20. Three replicas were made for each test procedure and bacterial counts were logarithmically transformed in order to calculate bacterial $\log 10$ reduction using the following equation according to Jimenez et al. (2010):

$(\log 10$ initial count $-\log 10$ final count $)=$ Bacterial $\log 10$ reduction

\section{Data analysis}

Analysis of variance (ANOVA) was performed using Bacterial Log10 reduction as response variable. Tukey test was used to determine differences between bacteria, ozonized oils and ozonization time with a significant level of $\leq 0.05$. Data were subjected to MINITAB 15 (2007) for statistical analysis.

\section{RESULTS AND DISCUSSION}

\section{Peroxide value}

The lowest peroxide value of $642.53 \mathrm{mmol}$-equiv/ $\mathrm{kg}$ was recorded when olive oil was ozonized for 6 hours; however, peroxide values of $703.7 \mathrm{mmol}$-equiv $/ \mathrm{kg}$ were obtained at 12 hours. On the other hand, the highest peroxide value of 892.12 mmol-equiv/kg was recorded when venadillo oil was ozonized 6 hours (Table 1).
Table 1 Determination of peroxide value for ozonized Olive and Venadillo oils

\begin{tabular}{lcc} 
Oils & Ozonization Time (h) & Peroxide Value ${ }^{*}$ \\
\hline \multirow{2}{*}{ Olive } & 6 & 642.53 \\
& 12 & 703.7 \\
Venadillo & 6 & 892.12 \\
\hline "Expressed in mmol-equiv $\cdot \mathrm{kg}^{-1}$ & &
\end{tabular}

\section{Minimum inhibitory concentration (MICs)}

When olive oil was ozonized 6 hours, the MIC's values for E. coli and S. aureus were $8.5 \mathrm{mg} / \mathrm{mL}$ and $3 \mathrm{mg} / \mathrm{mL}$, respectively. Olive oil ozonized during 12 hours showed MIC's values of $4.5 \mathrm{mg} / \mathrm{mL}$ and $2.5 \mathrm{mg} / \mathrm{mL}$ for $E$. coli and $S$. aureus, respectively. Ozonized venadillo oil at 6 hours reported MIC's values of 4.5 $\mathrm{mg} / \mathrm{mL}$ and $1.5 \mathrm{mg} / \mathrm{mL}$ for E. coli and $S$. aureus, respectively (Table 2).

Table 2 Antimicrobial activity of ozonized oils

\begin{tabular}{lcccccc}
\hline & \multicolumn{3}{c}{ Olive oil } & \multicolumn{2}{c}{ Venadillo Oil } \\
\cline { 2 - 7 } Microorganisms & \multicolumn{2}{c}{$6 \mathrm{~h}^{*}$} & & $12 \mathrm{~h}^{*}$ & \multicolumn{2}{c}{$6 \mathrm{~h}^{*}$} \\
\cline { 2 - 7 } & $\mathrm{MIC}^{\dagger}$ & $\log _{10} \mathrm{R}^{\ddagger}$ & $\mathrm{MIC}^{\dagger}$ & $\log _{10} \mathrm{R}^{\ddagger}$ & $\mathrm{MIC}^{\dagger}$ & $\log _{10} \mathrm{R}^{\ddagger}$ \\
\hline $\begin{array}{l}\text { Escherichia coli } \\
\begin{array}{l}\text { Staphylococcus } \\
\text { aureus }\end{array}\end{array}$ & 8.5 & 3.3 & 4.5 & 2.5 & 4.5 & 2.8 \\
\hline
\end{tabular}

"Ozonization time

Minimum inhibitory concentration expressed in $\mathrm{mg} \cdot \mathrm{mL}^{-1}$

${ }^{\ddagger}$ Bacterial $\log _{10}$ reduction

\section{Bacterial $\log 10$ reduction}

Table 2 shows the mean values of bacterial $\log 10$ reduction. The higher antimicrobial activity was observed when olive oil was ozonized during 12 hours against $S$. aureus (4 Log10). S. aureus showed a higher reduction than E. coli at any ozonized oils and time tested. ANOVA tests showed statistical differences in the response of bacteria against the ozonized oils $(p=0.000)$. However, no statistical differences were observed when ozonized oils where compared $(\mathrm{p}=0.154)$ or ozonization time was evaluated $(\mathrm{p}=0.260)$ (Table 3$)$.

Table 3 Effects of bacteria, ozonized oil and ozonization time over antimicrobia activity

\begin{tabular}{lcccc}
\hline Source & $\begin{array}{c}\text { Sum-of- } \\
\text { squares }\end{array}$ & $\begin{array}{c}\text { Degree of } \\
\text { freedom }\end{array}$ & $\boldsymbol{F}$-ratio & p-level $^{*}$ \\
\hline Bacteria & 2.6473 & 1 & 22.42 & 0.000 \\
Ozonized & 0.1337 & 1 & 2.28 & 0.154 \\
oil & 0.1629 & 1 & 1.38 & 0.260 \\
Time & 1.6530 & 14 & & \\
Error & & & & \\
\hline
\end{tabular}

alpha $\leq 0.05$ significance level

The primary target, when ozone is combined with vegetable oil are carbon to carbon double bonds of unsaturated fatty acids, favoring the formation of hydrogen peroxide as final product (Lezcano et al., 1998). Thus, the possible mechanism by which ozonized oil acts as an antimicrobial, is the oxidation of the microorganism through a slow release of peroxide (Ran et al., 2010). In previous studies, the ozonized olive oil (Oleozone) reported peroxide values between 500 and $800 \mathrm{mmol}$-equiv/kg, with optimal antifungal activity at $650 \mathrm{mmolequiv} / \mathrm{kg}$ (Ledea et al., 2010). Similar peroxide values (642 mmol-equiv/ $\mathrm{kg}$ ) were obtained with ozonized olive oil in the present study. However, the differences between Oleozone and the ozonized olive oil used in the present study were the ozonization method, and the time to reach the optimal peroxide level. The ozone bubbling method used to ozonize Oleozon is carried out during eight weeks and the electric shock field employed to ozonize the olive oil can be performed in hours. Even though, both procedures are easy to use, the ozonization time differs In this sense, the electric shock method optimizes time without affecting the formation of oxidized compounds. Also, no statistical differences were observed in the bacterial $\log 10$ reduction when olive oil was ozonized during 6 and 12 hours; therefore, 6 hours ozonization time can be adopted to optimize the ozonification process without affecting the antimicrobial activity.

On the other hand, venadillo oil generated high content of peroxide compounds due to the high presence of unsaturated fatty acids, allowing the production of various oxygenated compounds such as peroxides, ozonides and aldehydes, throughout the Criegee mechanism (Sechi et al., 2001; Solórzano-Santos and Miranda-Novales, 2010) thus, increasing its antimicrobial activity. Additionally, the statistical analysis showed no differences between ozonized venadillo and olive oils, confirming the antimicrobial effectiveness of the ozonized venadillo oil. The antimicrobial evaluation of both ozonized oils showed greater efficacy against Gram (+) than Gram (-) bacteria (Table 2). Previous reports by Diaz et al. (2006) and Lezcano et al. (1998) documented that ozonized olive oil with 
peroxide values of 735 mmolequiv/kg against E. coli ATCC 10536 and $S$. aureus ATCC 6538 , showed MIC's results of $9.5 \mathrm{mg} / \mathrm{mL}$ and $4.5 \mathrm{mg} / \mathrm{mL}$, respectively. The results were better in this study, which can be due to change in the analyzed ATCC strain, different peroxide values and the ozonization procedure used. The MIC's results showed lower values when ozonized venadillo oil was evaluated against both bacteria. This could be related to the high value of peroxides formed in this oil; however, it is necessary to conduct specific studies to demonstrate the antimicrobial activity of venadillo active principles. Lopez-Pantoja et al. (2007) and Montevecchi et al. (2013) evaluated acetone, methanolic and ethanolic extracts of venadillo oil against $E$. coli and $S$. aureus; all extracts used at high concentrations (25 and 50\%) and inoculum levels of $1 \times 10^{8} \mathrm{CFU} / \mathrm{ml}$ and $1.5 \mathrm{x}$ $10^{8} \mathrm{CFU} / \mathrm{ml}$, respectively, were effective in controlling the growth of both bacteria, being $S$. aureus the most susceptible. Moreover, to our knowledge, the present study is the first report of evaluating ozonized venadillo oils against bacterial organisms (Travagli et al., 2010; Zanardi et al., 2013).

\section{CONCLUSION}

To date, threating of bacterial infections is a challenging task due to the appearance of resistance to antibiotics. Therefore the development of natural alternatives as a control agent is a focused of interest. Based on the results of the present study, it can be concluded that both ozonized venadillo and olive oils could be a natural alternative for treatment of bacterial infections. However, venadillo tree may represent a much better option because of its accessibility in the Mexican Pacific Coast and Central America. Nonetheless, additional studies are required to validate the potentiality of ozonized venadillo oil as an antibacterial agent in topical or oral applications.

\section{REFERENCES}

Alonso-Castro A.J., Villarreal M.L., Salazar-Olivo L.A., Gómez-Sanchez M., Domínguez F., Gárcia-Carranca A. (2011). Mexican medicinal plants used for cancer treatment: pharmacological, phytochemical and ethnobotanical studies. Journal of Ethnopharmacology, 133,945-972. http://dx.doi.org/10.1016/j.jep.2010.11.055

Association of Analytical Communities. (1969). Oficial method 965.33 Peroxide Value of Oil and fats. In: Washington DC: AOAC.

Bakkali F., Averbeck S., Averbeck D., Idaomar M. (2008). Biological effects of essential oils-a review. Food and chemical toxicology: an international journal published for the British Industrial Biological Research Association. 46,446-475. http://dx.doi.org/10.1016/j.fct.2007.09.106

Bassolé I.H., Juliani H.R. (2012). Essential oils in combination and their antimicrobial properties. Molecules. 17, 3989-4006. http://dx.doi.org/10.3390/molecules 17043989

Burt S. (2004). Essential oils: their antibacterial properties and potential applications in foods-a review. International journal of food microbiology. 1,223253. http://dx.doi.org/10.1016/j.ijfoodmicro.2004.03.022

Christaki E., Bonos E., Giannenas I., Florou-Paneri P. (2012). Aromatic Plants as a Source of Bioactive Compounds. Agriculture. 2,228-243. http://dx.doi:10.3390/agriculture2030228

Criegee R. (2003). Mechanism of Ozonolysis. Angewandte Chemie International Edition in English.14,745-752.

Díaz M., Hernández R., Martínez G., Vidal G., Gómez M., Fernández H., Garcés R. (2006). Comparative Study of Ozonized Olive Oil and Ozonized Sunflower Oil. Journal of the Braziliam Chemical Society.17,403-407. http://dx.doi.org/10.1590/S0103-50532006000200026

do Amarante G.F., Vieira A,C., Garino F. Jr., Severo R., Madruga M.S. Queiroga V. (2013). The sensitivity of bacterial foodborne pathogens to Croton blanchetianus Baill essential oil. Brazilian Journal of Microbiology. 44,11891194. http://dx.doi.org/10.1590/S1517-83822014005000009

Geweely N. (2006). Antifungal activity of ozonized Olive oil (OLEOZON). International Journal of Agriculture and Biology. 8,670-675. DOI:15608530/2006/08-5-670-675. http://www.fspublishers.org

Guinesi A.S., Andolfatto C., Bonetti I., Cardoso A.A., Passaretti J., Farac R.V. (2011). Ozonized oils: a qualitative and quantitative analysis. Brazilian Dental Journal. 22,37-40. http://dx.doi.org/10.1590/S0103-64402011000100006

Jiménez A., Mata R., Pereda-Miranda R., Calderón J., Isman M.B., Nicol R., Arnason J.T. (1997). Insecticidal Limonoids from Swietenia humilis and Cedrela salvadorensis. Journal of Chemical Ecology. 49,1981-1988 DOI:10.1023/B:JOEC.0000006460.25281.9d

Jimenez M., Martinez C.I., Chaidez C. (2010). Disinfecion alternatives for contact surfaces and toys at child care centers. International Journal of Environmental Health Research. 20, 387-394. http://dx.doi.org/10.1080/09603123.2010.491851

Kon K.V., Rai K.M. (2012). Plant essential oils and their constituents in coping with multidrug-resistant bacteria. Expert Review of Anti-Infective Theraphy. 10,775-90. http://dx.doi.org/10.1586/eri.12.57

Ledea O.E., Curtiellas V., Moleiro J., Garcés R., Díaz M.F., Martínez-Force E., Hernández C., Fernández I. (2010). Evidences of Oxidative Mechanism on Antibacterial Activity of Ozonized Sunflower Oil. Rev CENIC Cien Biol. 2,1-13.
Lezcano I., Nuñez N., Gutierrez M., Molerio J., Regeiferos M.G., Díaz W. (1998). Actividad in vitro del aceite de girasol ozonizado (Oleozon) frente a diferentes especies bacteriana. Rev CENIC Cien Biol. 29,46-49. ISSN 0258-6002 López-Pantoja Y., Escalante M.A., Martínez-Rodríguez C., Soto-Beltrán J., Chaidez-Quiroz C. (2007). Efecto Antimicrobiano de Extractos Crudos de Neem (Azadirachta Indica A. Juss) y Venadillo (Swietenia Humilis Zucc) contra E. coli, S. aureus y el bacteriófago P22. Bioquímica. 32,117-125. ISSN:0185-5751

Martínez G., Ledea O., Díaz M. (2006). Measurement of peroxidic species in ozonized sunflower oil. Ozone. Science \& Engineering. 28,181-185 http://dx.doi.org/10.1080/01919510600689356

Millezi A.F., Caixeta D.S., Rossoni D.F., Cardoso M.G., Piccoli R.H. (2012). In vitro antimicrobial properties of plant essential oils thymus vulgaris, cymbopogon citratus and laurus nobilis against five important foodborne pathogens. Ciência e Tecnologia de Alimentos. 32,167-172. http://dx.doi.org/10.1590/S0101-20612012005000021

Montevecchi M., Dorigo A., Cricca M., Checchi L. (2013). Comparison of the antibacterial activity of an ozonated oil with chlorhexidine digluconate and povidone-iodine. A disk diffusion test. New Microbiologica. 36,289-302.

Perez-Rubio V., Heredia J.B., Chaidez-Quiroz C., Valdez-Torres J.B., SalazarVilla E., Allende-Molar R., Angulo-Escalante M.A. (2012). Physicochemical characterization and fatty acid content of 'venadillo' (Swietenia humilis Zucc.) seed oil. African Journal of Biotechnology. 11, 6138-6142 http://dx.doi.org/10.5897/AJB11.2674

Ran Z., Li S., Huang J., Yuan Y., Cui C., Williams C.D. (2010). Inactivation of Cryptosporidium by ozone and cell ultrastructures. Journal of Environmental Sciences (China). 22, 1954-9. DOI:10.1016/S1001-0742(09)60345-4

Sechi L.A., Lezcano I., Nunez N., Espim M., Dupre I., Pinna A., Molicotti P., Fadda G., Zanetti S. (2001). Antibacterial activity of ozonized sunflower oil (Oleozon). Journal of Applied Microbiology. 90,279-284. DOI:10.1046/j.1365 2672.2001.01235.x

Solórzano-Santos F., Miranda-Novales M.G. (2012). Essential oils from aromatic herbs as antimicrobial agents. Current Opinion in Biotechnology. 2,136-141. http://dx.doi.org/10.1016/j.copbio.2011.08.005

Travagli V., Zanardi I., Valacchi G., Bocci V. (2010). Ozone and ozonated oils in skin diseases: a review. Mediators of Inflammation. 1-9. http://dx.doi.org/10.1155/2010/610418

Zanardi I., Burgassi S., Paccagnini E., Gentile M., Bocci V., Travagli V. (2013) What is the best strategy for enhancing the effects of topically applied ozonated oils in cutaneous infections?. BioMed Research International. 1-6. http://dx.doi.org/10.1155/2013/702949 